\title{
АНАЛІЗ ПРОФЕСІЙНОЇ ЕТИКИ ТА РОЛІ РОБОТИ СЕРЕДНЬОГО МЕДИЧНОГО ПЕРСОНАЛУ
}

\author{
L. M. Lykha, I. Ya. Hospodarskyy \\ I. Horbachevsky Ternopil National Medical University
}

\section{ANALYSIS OF PROFESSIONAL ETHICS AND THE ROLE OF THE WORK OF NURSING MEDICAL STAFF}

\begin{abstract}
Анотація. Глобалізаційні та інтеграційні процеси в суспільстві, динамічний розвиток медичних технологій, визнання світовою спільнотою проблеми фізичного, морального і соціального здоров’я як головного показника соціально-економічної зрілості, культури й успішності держави, соціальний запит на якість медичних послуг зумовлюють особливі вимоги до професійної діяльності середнього медичного персоналу загалом і медичних сестер зокрема. Медична сестра повинна успішно володіти фундаментальними та спеціальними знаннями й уміннями в питаннях комплексного догляду за пацієнтами, надавати медичну допомогу, що відповідає принципу гуманності, національним і світовим професійним стандартам, активно здійснювати профілактичну діяльність у сфері охорони здоров’я. У виконанні своїх фахових обов’язків медична сестра має керуватися нормами професійної моралі й етики.

Важливість професійних та особистісних рис актуалізує необхідність удосконалення змісту формування професійної етики майбутніх медичних сестер у навчально-виховному процесі, зокрема під час вивчення дисциплін соціально-гуманітарної, психолого-педагогічної, професійно-практичної підготовки, проведення навчально-дослідної, виховної роботи, виробничих практик, що визначено галузевими стандартами вищої медичної освіти.
\end{abstract}

Ключові слова: професійна етика; сестринська справа; професійна відповідальність.

Abstract. Globalization and integration processes in society, dynamic development of medical technologies, the world recognition of the physical, moral and social health problems as the main indicator of socio-economic maturity, culture and success of the state, social demand for the quality of medical services determine special requirements for professional activity of medical staff in general and nurses in particular. The nurse must successfully possess fundamental and specialized knowledge and skills in matters of comprehensive patient care, provide medical care that meets the principle of humanity, national and international professional standards, actively implement preventive activities in the field of health care. In performing her professional duties, the nurse must be guided by the norms of professional morality and ethics.

The importance of professional and personal traits highlights the need to improve the matter of modeling professional ethics of future nurses in the educational process, in particular when studying the disciplines of socio-humanitarian, psychological and pedagogical, professional and practical training, conducting educational research and activities, internship, that are defined by industry standards of higher medical education.

Key words: professional ethics; nursing; professional responsibility.

Вступ. Стандарти етики медичної сестри та акушерки виходять за рамки етичного кодексу. Ми знаходимо їх у культурі, філософії, праві, людському досвіді, релігії та, загалом кажучи, в євроатлантичній або християнській цивілізації. Йдеться особливо про тенденцію індивідуальної етики [6, с. 112]. Неможливо написати та кодифікувати всі правила поведінки та ситуації, з якими стикаються медсестри у повсякденній практиці.

() Л. М. Лиха, І. Я. Господарський
Ось чому потрібна постійна етична рефлексія, тобто постійний аналіз над правильністю зробленого вибору, не тільки з пацієнтом, а й у широко зрозумілих контактах всередині професійного середовища. Професія медичної сестри зобов'язує дотримуватися норм професійної етики та порядності не лише у робочий час.

Основи етичних знань - це основа роботи медсестер. Тому люди, які обирають це унікальне завдання, виконане для іншої людини, повинні 
керуватися продуманою, глибокою, внутрішньою мотивацією [5, с. 65]. Вибір медичної сестри не може бути випадковим. Однак слід враховувати, що ставлення медичних сестер до хворих, страждаючих і вмираючих людей є відображенням рівня духовної культури не лише цієї професійної групи, а й усього суспільства [1].

Мета статті - визначити фундаментальні та спеціальні знання й уміння у роботі середнього медичного персоналу.

Теоретична частина. Медсестра, крім проведення професійних процедур і терапії, передбачає прояв любові та співпереживання до інших людей. Моральні цінності сестринської професії вже давно $€$ предметом етики та теорії медсестринства. Моральні принципи, що регулюють роботу з пацієнтами, повинні мати вплив на медсестер при прийнятті рішень про пацієнтів. Для досягнення здатності надавати професійну та цілісну допомогу пацієнтам необхідні не лише професійні компетенції, а й відповідне моральне ставлення та міжособистісні навички. Медсестра також повинна мати відповідний розвинений емоційний інтелект. Йдеться про вміння читати емоції інших, особливо хворих, а також про здатність контролювати свої емоції.

Емоційний інтелект.

Емоційний інтелект складається з декількох елементів. Це самосвідомість, тобто адекватна оцінка рівня та стану своїх навичок та можливостей. Крім того, це ще й саморегуляція, тобто контроль над власними емоціями. Одним із елементів емоційного інтелекту є також емпатія, а отже, здатність співпереживати ситуації іншої людини (наприклад, у її біопсихолого-соціальних потребах) та розуміння її дій та рішень.

Професійна етика стосується медсестри як людини та її професії. Медсестра зазвичай значну частину свого життя присвячує цій роботі. У певному сенсі ця робота формує її, професійно та особисто. Робота має два аспекти: матеріальний та психологічний. Матеріальний - тому що забезпечує існування, тим самим дає перспективи для майбутнього і визначає повсякденне життя. Психологічний - адже вона дає самореалізацію з точки зору задоволення самоочікувань, водночас вибудовує особистісну професійну цінність, репутацію та добре ім'я в оточенні, а також задоволення фактом допомоги іншим людям.

Обов'язки медсестри.

Термін, який з'являється при розгляді професійної етики, - це деонтологія, тобто вивчення зобов'язань, які мають люди щодо певної професії, в даному випадку професії медсестри та акушерки. Це дає поради, як бути довіреною, чесною та професійною людиною: в межах професійної корпорації та в очах пацієнтів. Деонтологія висвітлює шляхи поведінки, оскільки містить основні етичні принципи медичного середовища. Як приклад, відомий, фундаментальний принцип, виражений у вигляді латинської maxim: primum non nocere (перш за все, не зашкодити).

В умовах надзвичайно швидкого прогресу, знань та медичних технологій сестринська справа в XXI столітті створює свій новий імідж. Сфера діяльності змінюється. I відкривається не лише свіжий погляд на медсестринство як науку, але й нові галузі медичних знань. Водночас, в епоху великих прогресів та культурних змін, світ цінностей похитнувся. Часто втрачаються і справжній сенс, і сутність близькості з іншою людиною, оскільки акцент робиться на витратах, економії життя, прибутку чи збитках. Це відображається на зростаючій відстані, яка відділяє людей одну від одної, і в міжособистісних контактах виникає певний холод. Однак криза цінностей, характерна для сучасного суспільства, не повинна стосуватися сестринської допомоги [7, с. 21].

Сестринська справа - професія, джерелом і сутністю якої $є$ турбота про людей. Це вимагає конкретного контакту з іншою людиною. Медсестра повинна ставитися до пацієнта як до людини, а не як до предмета й зазвичай спілкуватися з нею і турбуватися про неї. Ця близькість зобов'язує медсестру захищати людську гідність і людяність, як для пацієнта, так і для неї самої. Ця майстерність зближує людину з людиною не тільки в психологічному, але й етичному аспектах. Піклування про гідність стосується рівня духовного, морального та соціального життя. Приймаючи гідність іншої людини, вона приймає і гідність власну.

Професія медичної сестри - це самостійна професія, тому знання нормативно-правових актів, що регулюють цю практику, є важливими.

Окрім юридичної відповідальності, існує також моральна відповідальність, пов'язана із здійсненням професії, про яку йдеться у Кодексі професійної етики медсестри та акушерки. Він складається 3:

1) загальної частини - йдеться про професійну діяльність медсестер, їх особистісний розвиток та професійні організації самоврядування;

2) детальної частини - містить обов'язки медсестри перед людьми-помічниками, стосовно професійної практики, до колег та власної професії. 
Незважаючи на запаморочливий темп життя, незважаючи на багато труднощів, які він приносить, медсестра та акушерка повинні знайти час для роздумів над Кодексом професійної етики. На практиці медичні сестри повинні сприймати цей документ як особистий покажчик, який дає основну етичну орієнтацію в повсякденному житті. Використовуючи Кодекс, власні етичні знання та особистий досвід, медсестра та акушерка повинні приймати правильні рішення за власних обставин. Очікується, що медсестра не лише серйозно й оптимістично дивиться на життя, але й на моральні цінності та норми, почуття відповідальності за її поведінку [2, с. 165].

Очікування та вимоги суспільства, що стосуються як компетенцій медичних працівників, так і поведінки відповідно до етичних норм, зростають. Дотримуючись професійних стандартів у конкретних ситуаціях, медсестра має значний вплив на формування позитивного іміджу громадської думки щодо своєї професії. Дотримання правил професійної етики сприяє належній практиці та підвищує соціальну довіру.

У дослідженнях з питань сестринської етики часто виділяють такі напрямки:

1) стосунки медсестри та пацієнта;

2) відносини медсестри та інших працівників системи охорони здоров'я;

3) питання морального розвитку та роботи над собою.

Ці сфери розглядаються з точки зору моральних цінностей, особистих моделей для наслідування та 3 точки зору моральних обов’язків медсестер [4, с. 115].

Парадигма догляду.

Однією з моделей сестринської етики є євангельська етика догляду. Євроатлантична духовна культура базується на цінностях, що містяться в Біблії. Центральна тема етики піклування про інших закладена в притчі про Доброго Самарянина, що міститься в Євангелії від св. Луки (10.30-37). Повідомлення історії залишається дійсним, незалежно від сповіданого світогляду її читачів [3].

Біблійний самарянин може бути зразком для сучасного медичного персоналу, про що багато разів нагадував Папа Іван Павло II.

Кожна людина, незалежно від свого екзистенційного становища та соціальних умов, є людиною, і найвищою передумовою етики піклування $\epsilon$ захист цієї людини. Самарянин - це людина без забобонів, що підтверджує особисту гідність, яку не можна недооцінювати, особливо в драматичних обставинах життя. Він є зразком цілісної поведінки медичних сестер, їх ставлення до хворих, турботи не лише про страждаюче тіло, а й про дуже важливі духовні та психологічні потреби. Ставлення до турботи за прикладом Доброго Самарянина дозволяє пережити перевагу моральних цінностей над матеріальними. Маєтковий достаток та високий економічний статус самарянина не руйнували його чутливості до людських страждань. Сенс розвитку науки та економічних цінностей служить благу людини. 3 іншого боку, суть медичної та сестринської допомоги відповідно до етики догляду полягає у наданні допомоги пацієнту, перебуваючи з ним та для нього, і захищаючи його життя та здоров’я.

В епоху перевантаження технічними приладами та апаратами медсестра ще більше затребувана пацієнтами. Жодне, навіть найдосконаліше лікарняне забезпечення не запобігає виникненню ситуацій, коли доля, щастя та життя однієї людини безпосередньо залежать від чутливості, солідарності та рефлексу серця інших людей. Медсестрі потрібно більше зосередитися на тому, кого вона доглядає, а також забезпечити контакт пацієнта з його родичами.

Суб’єктом моралі є людина, яка через свою людяність, а не через соціальний статус, благородство чи симпатію - істота, гідна поваги. Догляд за своєю гуманістичною природою вимагає поводження з людиною - пацієнтом цілісно, тобто як до осіб психофізичного та духовного характеру.

Суть медсестринства - це дбайливий догляд. Турбота означає стан, що виникає в процесі розвитку людини, що спонукає її дбати про щось чи когось і вимагати чогось чи когось, а також захищати когось чи щось, підтримувати когось і ділитися з ним благами. Турботливість - це чутливість до чужого болю і страждань, це постійний пошук і відкриття нових та кращих рішень для людей, які потребують допомоги, вона визнає потреби хворої людини, а також захищає іï людську гідність і людяність.

Медсестринство як мистецтво.

Сестринська справа за своєю суттю, ймовірно, триватиме доти, поки існує життя на Землі. Попередник і творець професійної та сучасної сестринської справи Флоренс Найтінгейл відзначила, що догляд - найкрасивіше з мистецтв і потребує великої відданості. Медсестра, яка функціонує як морально відповідальна людина, повинна мати очі, які бачать, вуха, які чують, і серце, яке розуміє. Поважати етичні принципи необхідно для на- 
лежної практики професії медсестри. Прийняття відповідальності за хвору людину є ї основним обов’язком. Медсестра несе відповідальність не лише перед законом, а насамперед перед власною совістю [8].

Дегуманізація ставлень медичного персоналу не означає одразу професійну дегенерацію, а скоріше втрати сенсу цієї професії. Найпоширеніший і перший прояв і причина дегуманізації - це відмова від етичної саморефлексії.

Синтез знань та етики.

Не існує загального рецепту для ідеальної медсестри, акушерки чи лікаря. Протягом століть існували вказівки на ці професії, починаючи з присяги Гіппократа (помер близько 377 р. до н. е.). Зараз кодекс професійної етики медсестер та акушерки також оновлюється. Він повинен враховувати досягнення медицини та пов'язані з цим проблеми. Кожна медсестра постійно намагається об'єднати медичні знання з універсальними етичними вимогами. Цей процес здійснюється в сумлінні кожної людини. В етичній рефлексії та законодавстві останнім часом підкреслюється важливість положення про совість, тобто право відмовлятися від певної медичної практики, яку конкретна людина вважає вкрай неетичною.

Сестринська справа - це не лише професія, а й покликання, яке вимагає прийняття та представлення конкретного професійного ставлення. У середовищі медичних сестер дедалі більше дискусій на цю тему, в яких ця професія не завжди сприймається як унікальна. У минулому догляд вважався покликанням, сьогодні це розуміється скоріше як професія. Однак це спеціальна професія. Медичним сестрам потрібно «відчути» те, що вони роблять, щоб правильно працювати і допомагати хворій людині. Сестринська справа - прекрасна професія, хоча іноді ті, хто приймає рішення (бюрократи), ставляться до неї як до службової, технічної та вторинної діяльності, а медсестри - як до службовців. Тим часом це важка, відповідальна і важлива лікарська професія. Професіоналізм слід

\section{Список літератури}

1. Алексеева Е. Б. Воспитание нравственно-этической культуры медицинских сестер лечебного учреждения [Электронный ресурс] / Е. Б. Алексеева // Международный журнал экспериментального образования. - 2014. - № 10. - С. 22-25. - Режим доступа : https://expeducation.ru/ru/ article/view?id=6007. примирити зі співпереживанням, а також із втомою та сміливістю. Присутність із хворими, страждаючими і вмираючими вимагає мужності.

Основою професійної роботи медичних сестер повинні бути їх етичні позиції. Люди, які вибирають цю унікальну професію, повинні керуватися продуманою, глибокою, внутрішньою мотивацією. Ставлення медичних сестер до хворих, страждаючих і вмираючих людей відображає рівень культури не лише цієї професійної групи, а й усього суспільства.

Висновки та перспективи подальших досліджень. Отже, однією з найважливіших умов ефективного лікування є єдність дій лікуючого лікаря і середнього медичного персоналу. У терапевтичних, хірургічних й інших відділеннях завжди $\epsilon$ важкохворі, що потребують цілодобової уваги лікаря та медичної сестри.

Професія медичної сестри, крім медичної компетентності, потребує високого рівня емпатії та співпереживання до інших людей. Моральною основою професійної роботи медичних сестер повинні бути їх етичні позиції; ставлення медичних сестер до хворих, страждаючих і вмираючих людей відображає рівень культури не лише цієї професійної групи, а й усього суспільства; з огляду на це, медичним працівникам необхідно підтримувати й удосконалювати не тільки фахові знання та навички, але і пізнання в галузі медичної етики.

Перспективу подальших наукових пошуків вбачаємо в дослідженні:

- важливості професійно орієнтованих навчальних дисциплін у формуванні професійної етики майбутніх медичних сестер з урахуванням динамічних змін у медицині, психології, педагогіці;

- високого потенціалу виробничих практик, позааудиторної виховної роботи у формуванні професійної етики майбутніх медичних сестер;

- усвідомлення педагогами необхідності вдосконалення процесу формування професійної етики майбутніх медичних сестер та розроблення навчально-методичного забезпечення цього процесу.

2. Деонтология в медицине : в 2 т. / под ред. Б. В. Петровского. - М. : Медицина, 1988. - 506 с.

3. Дідівський А. Євангельська мораль як фундамент традиційної та сучасної православної етики / А. Дідівський // Наукові записки Національного університету «Острозька академія». Серія «Філософія». - 2015. - Вип. 
17. - С. 154-159. - Режим доступу : http://nbuv.gov.ua/ UJRN/Nznuoafs_2015_17_31.

4. Етика : навч. посіб. / [В. О. Лозовой, М. І. Панов, О. А. Стасевська та ін.] ; за ред. проф. В. О. Лозового. К. : Юрінком Інтер, 2002. - 224 с.

5. Иванюшкин А. Я. Этика сестринского дела / А. Я. Иванюшкин. - М. : ГРАНТ, 2003. - 168 с.

\section{References}

1. Alekseeva, E.B. (2014). Vospitanie nravstvennoeticheskoy kultury meditsynskyh sester lechebnogo uchrezhdeniya [Education of moral and ethical culture of nurses of a medical institution]. Retrieved from: https:// expeducation.ru/ru/article/view?id=6007 [in Russian].

2. Petrovskyy, B.V. (Ed). (1988). Deontologia v meditsyne [Deontology in medicine]. Moscow: Meditsina [in Russian].

3. Didivskyy, A. (2015). Evanhelska moral yak fundament tradutsiinoi ta suchasnoi pravoslavnoi etyky [Evangelical morality as the foundation of traditional and modern Orthodox ethics]. Naukovi zapysky Natsionalnoho universytety “Ostrozka akademia”. Seriia: Filisofia. Vyp.17 - Scientific Notes of the National University “Ostroh Academy”. Series: Philosophy. Vol.17. Retrieved from: http://nbuv.gov.ua/UJRN/Nznuoafs_2015_17_31 [in Ukrainian].
6. Лещинский А. А. Медицинская этика и деонтология / А. А. Лещинский. - Ижевск, 2005. - 250 с.

7. Островская И. В. Медицинская этика. Сборник документов / И. В. Островская. - М. : АНМИ, 2001. - 40 с.

8. Персильева Г. М. Памяти Флоренс Найтингейл / Г. М. Персильева // Медична сестра. - 2000. - № 2. C. 2-11.

4. Lozovoy, V.O. (Ed.). (2002). Etyka: navch. posib. [Ethics]. Kyiv: Urinkom Inter [in Ukrainian].

5. Ivanushkin, A.Ya. (2003). Etyka sestrinskogo dela. [Ethics of nursing]. Moscow: GRANT [in Russian].

6. Leshchynskyy, A.A. (2005). Mediysinskaya etika i deontologiya [Nursing ethics and deontology]. Izhevsk [in Russian].

7. Ostrovskaya, I.V. (2001). Meditsynskaya etika. Sbornik dokumentov [Medical ethics. Digest of documents]. Moscow: ANMI [in Russian].

8. Persyleva, G.M. (2000). Pamyatu Florens Naytingeyl [For a memory of Florence Nightingale]. Medychna sestraNurse, 2, 2-11 [in Ukrainian].
Отримано 05.10.20

Рекомендовано 08.10.20 